\section{"HYPOTHESES FINGIMUS": CARTESIAN NATURAL PHILOSOPHY}

Abstract: In this paper, I would like to present the methodological views of two representatives of the early modern Cartesian school: Jacques Rohault and Pierre-Sylvain Régis. Firstly, I want to present the methodological objections of Cartesians to Aristotelian and Scholastic natural philosophy. Then, I want to show how Cartesians strived for a combination of empirical and speculative procedures in their explanations of natural processes. Lastly, I would like to explain the reasons and forms of the hypothetical methodology which was significant for Cartesian natural philosophy. My aim is to refute the idea of the methodological naivety of Cartesians and point out the importance of hypothetical reasoning in the genesis of modern science.

Keywords: René Descartes; early modern natural philosophy; mechanical philosophy; hypotheses; experimentalism

\section{„Hypotheses fingimus“: Karteziánská př́írodní filosofie}

Abstrakt: $V$ tomto článku chci predstavit metodologické názory dvou predstavitelù novověké karteziánské školy: Jacquese Rohaulta a Pierre-Sylvaina Régise. Přednè chci predstavit metodologické námitky karteziánů proti aristotelské a scholastické filosofii. Dále chci ukázat, jak karteziáni usilovali o kombinaci empirických a spekulativních postupů $v$ jejich vysvětleních prírodních procesů. A nakonec chci vysvětlit diovody a formy hypotetické metodologie, která byla př́značná pro karteziánskou prírodní filosofii. Mým cílem je vyvrátit myšlenku metodologické naivity karteziánů a zdůraznit úlohu hypotetického uvažování při utvářrení moderní vědy.

Klíčová slova: René Descartes; novověká prírodní filosofie; mechanistická filosofie; hypotézy; experimentalismus

\section{DANIEL ŠPELDA}

Faculty of Arts, Masaryk University Arna Nováka 1, 60200 Brno email / spelda@phil.muni.cz (iD) 0000-0002-1717-6729

This study was supported by the project "The Idea of Scientific Progress in the Early Enlightenment (1684-1740): Fontenelle and His Contemporaries" (20-01948S) of the Czech Science Foundation.

(c) (i) This work is licenced under the Creative Commons Attribution 4.0 International License. 


\section{Introduction}

During Descartes's lifetime and after his death, a group of philosophers and other thinkers emerged who identified with his philosophy. Some came to their own metaphysical position, which was called occasionalism, others followed different aspects of Descartes's philosophical program. ${ }^{1}$ The Cartesian School did not acquire a good reputation in the subsequent history of philosophy and science. Specifically, in the field of natural philosophy (or science), Cartesians were criticized for their aim to explain the natural world deductively and for underestimating experience and experimentation. ${ }^{2}$ This criticism is partially correct. It is a fact that of Descartes's followers, only those who were able to deviate from him achieved success in natural philosophy and sciences - such as Edme Mariotte (1620-1684) or Christiaan Huygens (1629-1695). On the other hand, recent research has made it clear that the methodology of Cartesian natural philosophy cannot be reduced to mere speculative rationalism. Scholars such as Trevor McClaughlin, Mihnea Dobre and Sophie Roux, demonstrated that experimentalism was not solely an English phenomenon. There was an experimental tradition present in the French intellectual culture, which Cartesians took part in. ${ }^{3}$

\footnotetext{
${ }^{1}$ I do not want to engage in the debate about the members of the Cartesian school/movement, see most recently Steven Nadler, Tad M. Schmaltz, and Delphine Antoine-Mahut, eds., The Oxford Handbook of Descartes and Cartesianism (Oxford: Oxford University Press, 2019), 271-565.

${ }^{2}$ Jean Le Rond D’Alembert, "Discours préliminaire des editeurs," Encyclopédie our Dictionnaire raisonné des sciences, des arts et des métiers, eds. Denis Diderot and Jean Le Rond D’Alembert (Paris: Briasson, 1751), xxvii.

${ }^{3}$ See Trevor McClaughlin, "Was There an Empirical Movement in Mid-seventeenth Century France? Experiments in Jacques Rohault's Traité de physique," Revue d'histoire des sciences 49 (1996): 459-80; Trevor McClaughlin, "Descartes, Experiments, and a First Generation Cartesian, Jacques Rohault," in Descartes's Natural Philosophy, eds. Stephen Gaukroger, John Schuster, and John Sutton (London: Routledge, 2000), 330-42; Sophie Roux, "Was There a Cartesian Experimentalism in 1660s France?," in Cartesian Empiricisms, eds. Mihnea Dobre and Tammy Nyden (Dordrecht: Springer, 2013), 47-88; Sophie Roux, "An Empire Divided: French Natural Philosophy (1670-1690)," in The Mechanization of Natural Philosophy, eds. Daniel Garber and Sophie Roux (Dordrecht: Springer, 2013), 55-96; Sophie Roux, "The Two Comets of 1664-1665: A Dispersive Prism for French Natural Philosophical Principles," in The Idea of Principles in Early Modern Thought, ed. Peter R. Anstey (London: Routledge, 2017), 98-147; Mihnea Dobre, "Jacques Rohault and Cartesian Experimentalism," in The Oxford Handbook of Descartes and Cartesianism, eds. Steven Nadler, Tad M. Schmaltz, and Delphine Antoine-Mahut (Oxford: Oxford University Press, 2019), 47-88; Mihnea Dobre, "Rohault's Cartesian Physics," in Cartesian Empiricisms, eds. Mihnea Dobre and Tammy Nyden (Dordrecht: Springer, 2013), 203-26.
} 
Following on from this research, I try to present the methodological views of two Cartesians: Jacques Rohault and Pierre-Sylvain Régis.

Jacques Rohault (1618-1672) was the author of the textbook of Cartesian physics Traité de physique published in 1671. It was translated into Latin in 1674; a new Latin translation was published in $1697 .{ }^{4}$ The Latin version of the treatise was widely used at universities in Western Europe as a clear interpretation of mechanistic physics, cosmology and physiology. The treatise was translated into English in 1723. Newton's follower Samuel Clarke supplemented and corrected it with notes based on Newton's natural philosophy. ${ }^{5}$ This edition was published several times in England and was widely used at British universities. ${ }^{6}$

Traite de physique is believed to provide a summary of the lectures Rohault held in Paris in the 1660s. In his lectures, Rohault presented the foundations of Cartesian natural philosophy to a broad audience. Rohault was not interested in Descartes's metaphysical foundations of natural philosophy and rather reduced their importance to natural philosophy. In contrast, he emphasized the role of the experiment. We have, for example, the testimony of Rohault's father-in-law Claude Clerselier (1614-1684), who published both Rohault's and Descartes's writings. In his introduction to the collection of Rohault's mathematical textbooks, he enumerates Rohault's experiments on light, vision, magnet, emptiness, rainbow, pressure in liquids, etc. ${ }^{7}$ Roux, McClaughlin, and Dobre demonstrated, however, that the goal of Rohault's experiments was not to discover something new, nor to convincingly validate any Cartesian hypothesis. The goal of his experiments was rather didactic and illustrative. ${ }^{8}$

Pierre-Sylvain Régis (1632-1707) first attended Rohault's lectures in Paris, later giving similar lectures in Toulouse (1665-1671) and then in Montpellier (1671-1680). Similar to Rohault, Régis conducted a number of

${ }^{4}$ Jacob Rohault, Tractatus physisus cum animadversionibus Antonii le Grand (Amstelaedami: Wolters, 1700).

${ }^{5}$ I this paper I quote later edition: Jacques Rohault, System of Natural Philosophy Illustrated with Dr. Samuel Clarke's Notes Taken Mostly Out of Sir Isaac Newton's Philosophy, 2 vols. (London: John - Knapton, 1735).

${ }^{6}$ Volkmar Schüller, "Samuel Clarke's Annotations in Jacques Rohault's Traité de Physique, and How They Contributed to Popularising Newton's Physics," in Between Leibniz, Newton, and Kant, ed. Wolfgang Lefèvre (Dordrecht: Springer, 2001), 95-110.

${ }^{7}$ Claude Clerselier, "Préface," in Jacques Rohault, Oeuvres posthumes (Paris: Desprez, 1687), unpaginated.

${ }^{8}$ Roux, "Was There a Cartesian Experimentalism in 1660s France?," 74-76; McClaughlin, "Descartes, experiments," 478; Dobre, "Rohault's Cartesian Physics," 223. 
experiments in his lectures. After his return to Paris from the provinces in 1680, Régis tried to publish his own overview of Cartesian philosophy (1690). ${ }^{9}$ Due to the theological controversies, he was not able to receive approval to publish his Cours entier de philosophie ou Système général selon les principles de Descartes until $1690 .^{10}$ In his work, Régis did not focus only on natural philosophy, but he also developed other parts of the Cartesian philosophy composing his book in analogy to the structure of scholastic philosophical textbooks. ${ }^{11}$

I want to focus on three problem areas that appear in both texts. The first is the critique of Aristotelian scholastics, the second is the combination of empirical and speculative procedures in natural philosophy. The third topic of my paper is the status of hypotheses in Cartesian natural philosophy.

\section{Against Aristotle}

In his preface to Traité de physique, Rohault makes clear his belief in the continuous and cumulative advancement of natural philosophy in the course of time:

For as a great Number of Persons who cultivate the same Art or Science for several succeeding Ages add their own Industry, and their Light to the ancient Discoveries of those who went before them, it is impossible but that such an Art or Science must receive great Improvement, and arrive nearer and nearer to its utmost Perfection. ${ }^{12}$

For Rohault, cultivating science is a collective effort that takes place over time. Generations of researchers pass on the results of their work over the ages, and so Rohault can metaphorically say that time is favourable to the advancement of science.

Not all the disciplines progressed in the same way. Rohault also points out that there was a "vast progress" of the mathematical disciplines. Following Francis Bacon, he also emphasizes the progress of the arts and

\footnotetext{
${ }^{9}$ In this paper, I use the two-volume edition which was published under the title Système de philosophie, contenant la logique, la métaphysique, la physique et la morale (Paris: Thierry, 1690).

${ }_{10}$ Tad Schmaltz, Early Modern Cartesianisms. Dutch and French Constructions (Oxford: Oxford University Press, 2017), 301.

${ }^{11}$ Dennis Des Chene, "Cartesian Science: Régis and Rohault," in Blackwell Companion to Early Modern Philosophy, ed. Steven Nadler (Oxford: Blackwell, 2002), 183-96.

${ }^{12}$ Rohault, Traité, unpaginated "Préface"; Rohault, System, unpaginated "Preface."
} 
crafts. Unfortunately, this progress did not afflict natural philosophy: "the twenty Ages have passed, without any new discovery made in it [i.e., natural philosophy]."13

This was a standard Cartesian view: there was nothing special about philosophy between Aristotle and Descartes, only speculation, nonsense and superstition. Only Descartes's philosophy brought liberation from the tenets of authority. This is the pathos found in Descartes's Discourse on the Method, ${ }^{14}$ but also in Nicolas Malebranche, ${ }^{15}$ or in Fontenelle's account of the beginnings of the French Academy in the 1660s. For Fontenelle, Descartes brought a long period of barbarism to an end and his philosophy ended with a domination of authority and teaching sterile physics. ${ }^{16}$

In his preface, Rohault further asks what the reasons behind this retardation were and he identifies five "defects" (defauts) preventing the advancement of natural philosophy.

The first defect is too much authority (grand credit) that had always been given to the Ancients at universities. Rohault stands firmly on the side of the Moderns. He believes that the minds of modern authors do not fall behind the minds of the Ancients, and therefore there is no reason for the Moderns to feel inferior to the Ancients. The blind worship of Aristotle in universities has stopped progress. The belief that Aristotle "knew all that could be known" resulted in mere commenting on his philosophy "without promoting Science at all."17

These words reveal that Aristotle's natural philosophy did not bother Rohault primarily because it was wrong. Rohault (and other Cartesians) condemned scholastic philosophy because it was knowledge that relied ultimately on authority for its justification. At the end of his Preface, Rohault even writes that in his book there is not much against Aristotle, but a lot against his commentators. The problem, then, is not Aristotle's philosophy in itself, but the blind following of ancient philosophy which does not respect new discoveries, findings and theories. Instead of commenting on ancient authors and filling the lacunas in their works, the vision of collective

\footnotetext{
${ }^{13}$ Ibid.

${ }^{14}$ René Descartes, Euvres, eds. Charles Adam and Paul Tannery (Paris: Vrin, 1897-1913, further only as $A T$ ), vol. VI, $12 \mathrm{f}$.

${ }^{15}$ Nicolas Malebranche, De la recherche de la verité in Nicolas Malebranche: Oeuvres, ed. Geneviève Rodis-Lewis (Paris: Gallimard, 1979), vol. I, 212-14, 217-29, 237-42.

${ }^{16}$ Bernard de Fontenelle, Histoire de l'Académie Royale des sciences (Paris: Martin - Coignard, 1733), vol. I, 1f.

${ }^{17}$ Rohault, Traité, unpaginated "Préface”; Rohault, System, unpaginated "Preface."
} 
collaboration and the slow long-term improvement of knowledge over time emerge in Rohault's Preface.

As a second defect preventing the development of natural philosophy, Rohault identifies the cultivation of natural philosophy in an overly metaphysical spirit. Rohault emphasizes that natural philosophers dealt too much with abstract natural philosophical concepts and issues such as the definition of motion or the question of the divisibility of matter. Instead, they should have studied particular phenomena. It is precisely the explanation of partial phenomena that is useful in contrast to abstract metaphysical considerations. ${ }^{18}$ Rohault does not want to create natural philosophy as part of a great philosophical system - it is much more important for him to provide the explanations of partial phenomena. On the other hand, it is worth reminding that Rohault's position of simple physicien was not typical for Cartesians. For example, Régis consciously wanted to integrate physics into a comprehensive system of Cartesian philosophy. This is also reason of the debate about why Rohault left out the metaphysical foundations of Cartesian physics from his version of it. While some writers insist that Rohault wanted to avoid the theological implications of Cartesian cosmology, other interpreters, such as Aaron Spink recently, have sought to find methodological reasons for Rohault's abstinence from metaphysics - especially his empiricism and experimental approach to knowledge and hypotheses testing. ${ }^{19}$

The third defect, "which hinders the Progress of Natural Philosophy" is the presence of two methodological extremes in natural philosophy. In the first case, the reasoning is overrated; in the second case, the experience is overestimated. As this is methodologically the most important part of Rohault's Preface, I will return to this point in the second part of this paper.

The fourth defect preventing progress is the neglecting of mathematics. That sounds very Newtonian and modern but we should avoid an anachronist reading of these words. There is hardly any mathematics in Rohault's treatise, although Rohault was a skillful mathematician, as can be seen in the mathematical textbooks Clerselier published posthumously. Here Rohault presents his interpretation of Euclid, which falls into the realm of pure mathematics. However, what follows is a treatise on "mixed mathematics" - that is, in the field of mechanics and optics. ${ }^{20}$ Also Mihnea Dobre in his

\footnotetext{
${ }^{18}$ Ibid.

${ }^{19}$ Aaron Spink, "The Experimental Physics of Jacques Rohault," British Journal for the History of Philosophy 26, no. 5 (2018): 850-70.

${ }^{20}$ On distinction "pure" and "mixed" mathematics see, e.g., Peter Harrison, "Physicotheology and the Mixed Sciences," in The Science of Nature in the Seventeenth Century. Patterns of
} 
recent paper shows that Rohault was considered a mathematician by his contemporaries and that he was involved in discussion about problems of the mixed mathematics. ${ }^{21}$ In his Traité, however, Rohault followed Descartes's physics as laid out in the Principia philosophiae. That is, Rohault explains natural phenomena through micromechanical models, which, however, do not have mathematical parameters and do not allow predictions to be calculated.

Rohault's physics was therefore as qualitative as Descartes's physics, or Aristotle's. So why is mathematics important? Rohault only generally points out the number of useful truths contained in mathematics. He further states that mathematics cultivates the human mind - that is, mathematics teaches what a rigid demonstration is, how to know the truth and how to follow reason (ceder à la raison). ${ }^{22}$ This, in turn, was a typical Cartesian motif: Mathematics serves primarily to cultivate intellectual virtues. ${ }^{23}$ According to Rohault, mathematical cultivation of the mind is a good means of preventing people from falling into error and into endless disputes. The last and greatest benefit of mathematics lies in the fact that it accustoms the human mind to perceiving shapes (figures). This enables the human mind to better imagine the shapes of particles that can produce observable effects.

The meaning of Rohault's words is obvious: What should be mathematicized is not nature, but the human mind or spirit (esprit). Mathematics teaches the mind to think properly, but it is not a privileged procedure for explaining natural phenomena. There is no mention of the mathematization of phenomena, of their conversion into quantity, or of the mathematical description of movement for example. This shows how far Rohault was not only from Newton but also from other continental scientists, such as Christiaan Huygens.

In Rohault's list of defaults, the last one is the aversion encountered by authors who come up with something new and original. They are denounced and despised mostly because they deviate from Aristotle. This complaint is,

Change in Early Modern Natural Philosophy, eds. Peter Anstey and John Schuster (Dordrecht: Springer, 2008), 165-83; Daniel Garber, "Philosophia, Historia, Mathematica: Shifting Sands in the Disciplinary Geography of the Seventeenth Century," in Scientia in Early Modern Philosophy, eds. Tom Sorell, G. A. J. Rogers, and Jill Kraye (Dordrecht: Springer, 2010), 1-19.

${ }^{21}$ Mihnea Dobre, "Jacques Rohault's Mathematical Physics," HOPOS: The Journal of the International Society for the History of Philosophy of Science 10, no. 2 (2020): 414-39.

${ }^{22}$ Rohault, Traité, unpaginated "Préface"; Rohault, System, unpaginated "Preface."

${ }^{23}$ Philippe Hamou, "Sur les origines du concept de méthode à l'âge classique: La Ramée, Bacon et Descartes," Revue LISA 12, no. 5 (2014). 
of course, the result of Rohault's progressive understanding of the history of natural philosophy, which evaluates innovation as a step further, not as a detrimental deviation from tradition. Similarly as Descartes, ${ }^{24}$ Rohault believed in the possibility of complete physics. That means that the moment would come when humans would have a final and closed physical system. Belief in the advancement of science, was not belief in the infinity of progress. There will be a day when human beings understand nature completely and they become wise masters of nature.

\section{Reasoning and Experience}

Descartes seems to cherish the ideal of physics deduced from established first truths. His aim was to achieve certain physical knowledge which would "have been deduced in an unbroken chain from the first and simplest principles." ${ }^{25}$ Such knowledge is not certain because it corresponds to the empirical reality but rather because it is a part of a deductive system of propositions. The problem was that the certainty resulting from the uninterrupted deduction of physical explanations from metaphysical principles concerned only the general arrangement and behaviour of the natural world and could not be transferred to the explanation of specific empirical phenomena. Thus, Descartes could derive general laws of behaviour of material particles, such as the rules of their collisions, but not the behaviour of bodies in particular natural processes - for example, the burning of a candle.

In the Discourse on the Method, Descartes explains that he gradually deduced from the basic principles the general arrangement of nature, heaven, stars and earthly matter. Then, when he sought to explain particular phenomena, he encountered such a variety that he did not think:

the human mind could possibly distinguish the forms of species of bodies that are on the earth from an infinity of others that might be there if it had been God's will to put them there. Consequently, I thought the only way of making these bodies useful to us was to progress to the causes by way of the effects and to make use of many special observations. ${ }^{26}$

\footnotetext{
${ }^{24}$ René Descartes, Discourse de la Méthode, AT VI, 19

${ }^{25}$ René Descartes, Principia philosophiae, AT VIII, 328, quoted from The Philosophical Writings of Descartes, trans. John Cottingham, Robert Stoothoff, and Dugald Murdoch (Cambridge: Cambridge University Press, 1985), vol. I, 290.

${ }^{26}$ Descartes, Discourse de la Méthode, AT VI, 64; quoted from Descartes, Discourse on the Method in The Philosophical Writings, 144. Cf. Desmond Clarke, "Descartes's Philosophy of
} 
That means that physical principles only define possibilities. The form and course of specific natural processes cannot be determined a priori, although the principles governing and explaining their occurrence and behaviour are independent of empirical confirmation. Therefore, Descartes had to admit that we needed experience if we wanted to explain particular phenomena. Concrete explanations of particular processes follow from the general physical principles while respecting empirical findings. For instance, it can be deduced from the principles that there can be no vacuum in the world, but it is not possible to deduce in this way how air pressure changes depending on altitude. Therefore, Descartes proposed an experiment to Pascal, which was eventually performed on Puy de Dôme. ${ }^{27}$

In Descartes's natural philosophy, there was a tension between purely rational ambition and the necessity to take experience and experimentation into account. This tension, which Descartes never managed to solve, is also to be found in the physics of his followers.

In the methodological part of his work, Régis presented two forms of physics. ${ }^{28}$ There is practical physics (la physique pratique), which is based on the knowledge of effects (la connoissance des effets). It deals with the observation of all the effects that a physical body can produce. The second is speculative physics (la physique spéculative), which consists in knowing the causes (la connoissance des causes). It is based on reasoning (raisonnemens) which intends to discover the causes of natural phenomena. According to Régis, such a sharply conceived dichotomy is misleading. Both opinions are extreme and do not provide good results, points out Régis. Ancient philosophers preferred speculative physics and favoured reasoning too much. Modern philosophers favour practical physics and reduce physics to the discovery of new facts (découverte de nouveaux faits). ${ }^{29}$ According to Régis, if we want to bring physics to perfection, we have to join its speculative and practical part. A system of natural philosophy must combine both types of physique. Régis explains that deductive speculative physics in itself is unable

Science and the Scientific Revolution," in The Cambridge Companion to Descartes, ed. John Cottingham (Cambridge: Cambridge University Press, 1992), 259-85; Desmond Clarke, Descartes's Philosophy of Science (Manchester: Manchester University Press, 1982); Peter Dear, Discipline and Experience: The Mathematical Way in the Scientific Revolution (Chicago: University of Chicago Press, 1995), 136-38, 180-209; Ernan McMullin, "Explanation as Confirmation in Descartes's Natural Philosophy," in A Blackwell Companion to Descartes, eds. Janett Broughton and John Carriero (Oxford: Blackwell, 2008), 84-102.

${ }^{27}$ René Descartes, Letter to Mersenne, $13^{\text {th }}$ December 1647, AT V, 99.

${ }^{28}$ Régis, Système de philosophie, vol. I, 274.

${ }^{29}$ Ibid. 
to grasp particulars and practical physics in itself can accumulate partial factual findings to infinity.

Rohault expressed a similar view in the third point of his list of shortcomings that prevented physics from further progress. The third defect was overestimating two methodological extremes: excessive rationalism and excessive empiricism. Rationalism emphasizes too much "reasoning" (raisonner). This philosophy neglects experiments and emphasizes arguments - "especially if they [i.e., arguments] be borrowed from the Ancients." ${ }^{30}$ The scholastics are the representatives of this attitude. The second position is enthusiastic empiricism which emphasizes experiment (experience in the French original). Rohault writes about the empiricists: They "think every Thing ought to be reduced to Experiment (tout reduire en experience), and [...] there should be no Reasoning at all. But both these Extremes do equally hinder the Progress of Natural Philosophy." ${ }^{11}$

In their critique of excessive empiricism, Régis and Rohault reacted to the development of experimental physics. Rohault was hardly thinking of English empiricists and experimentalists who took part in the meetings of the Royal Society of London. He more likely had his countrymen in mind. Trevor McLaughlin and Sophie Roux have convincingly shown that in $17^{\text {th }}$ century France, there was a relatively strong and significant tradition of experimental philosophy focused on performing experiments or collecting data.

Probably Blaise Pascal is the best-known French experimentalist of this period but there were also authors who had created academic circles like the Académie Montmor and Académie Thévenot (called also Compagnie des sciences and des arts). Some of their representatives later became members of the French Academy of Sciences (1666) where Cartesians were not initially invited. The list of experimentalists and empiricists participating in activities of both academies included astronomers such as Adrien Azout (16221691) and Pierre Petit (1598-1682), medical doctor Jean Pecquet (1622-1674), or foreign visitors such as Christiaan Huygens, Nicolas Steno (1638-1686) and Jan Swammerdam (1637-1680). Sophie Roux sets the flowering of this movement in the 1660s: "from 1662 through 1666, radical experimentalism was present everywhere and in all sorts of manners." 32 Roux also points out that Rohault gradually alienated these experimental scientists. For example,

\footnotetext{
${ }^{30}$ Rohault, Traité, unpaginated "Préface"; Rohault, System, unpaginated "Preface."

${ }^{31}$ Ibid.

${ }^{32}$ Roux, "Was There a Cartesian Experimentalism in 1660s France?," 67.
} 
Huygens wrote in 1693 that Descartes's followers waste time examining their master's work instead of exploring nature itself. ${ }^{33}$

Régis and Rohault were clearly aware of the importance of an experimental approach. However, they also shared Descartes's great vision of physics as a system of propositions deduced from basic and certain principles. Their solution was therefore half-hearted and unclear: a vague call for reconciliation and a combination of both approaches.

Régis distinguished two types of physics on the basis of two methodologically distinct components of his physical system. At the top, there is a set of non-empirical propositions called the first truths (les premieres verités). Régis provides a list of six such truths: there is a physical nature that can be described quantitatively; it is divisible; it is divided by movement; movement takes place according to certain rules (règles) and so on. These six general principles provide a general framework for physical explanation. Régis considers them to be certain and demonstrated because they are derived from demonstrated or evident metaphysical truths. Ideally, deduction would continue to particular natural phenomena. But Régis admits that this is not possible. In case of particular phenomena, we must start with their effects if we want to proceed to the knowledge of their causes. ${ }^{34}$ Therefore, if we want to approach particular phenomena, we need to proceed empirically. The general principles set the general ontological framework and conceptual boundaries for creating partial explanations which must always take experience into consideration.

In the fifth chapter of his Traité, Rohault himself similarly presents eight non-empirical axioms of physics such as: "No substance can be annihilated," "Every effect presupposes some cause," or even "There are also other similar axioms." Rohault explains that further axioms are less general and will be discussed in the appropriate context. ${ }^{35}$ Rohault also wants to avoid the metaphysical and theological justification of these axioms and thus simply considers them as evident. ${ }^{36}$ Similarly as Régis, Rohault emphasizes that we need to allow for experience in explaining particular phenomena. But even if Rohault admits the necessity of empirical procedures, he does not acclaim empirical science. According to Rohault, both procedures, reasoning and experience, are too deficient. Experience is too narrow, while thinking is

\footnotetext{
${ }^{33}$ Christiaan Huygens, "De la vie de M. des Cartes par Baillet," Euvres complètes (La Haye: Nijhoff, 1888-1950), vol. X, 405.

${ }^{34}$ Régis, Système de philosophie, 277.

${ }^{35}$ Rohault, Traité, unpaginated "Préface"; Rohault, System, unpaginated "Preface."

${ }^{36}$ Ibid.
} 
too broad: "we must mix these two Means of Knowledge together, and join Reason with Experiments" (de mêler experiences au raisonnement). ${ }^{37}$

To make his idea more clear, Rohault suggests distinguishing three types of experience (experience in the French original, experiments in the English translation). ${ }^{38}$ The first type of experience is mere observation, which is often random and without a specific goal, as Rohault points out. The second type is a designed experience that does not include knowing what will happen: "when we deliberately and designedly make Tryal of any Thing, without knowing or foreseeing what will come to pass" (mais sans sçavoir ny prévoir ce qui pourra arriver). ${ }^{39}$ An example of such a practice is the activity of alchemists or craftsmen such as glassmakers or goldsmiths. It is a random exercise of various experiments that come to human minds without any methodological order. This exercise sometimes results in random discoveries, such as gunpowder or telescope.

The third type of experience is the anticipated experience. Rohault speaks of experiments "which are made in Consequence of some Reasoning in order to discover whether it was just or not (celles que le raisonnement previent, \& qui servent à justifier ensuite s'il est faux, ou s'il est juste)." ${ }^{\prime \prime 0}$ Rohault emphasizes that this third kind of experience is the most useful to philosophers because it "discovers to them the Truth of Falsity of the Opinions (découvrir la verité)." ${ }^{\prime 1}$ This kind of experience is supposed to combine reasoning and experience. Initially, there is a rational consideration followed by an experiment or other empirical procedure to determine whether or not the reasoning is wrong. Therefore, anticipated experience is based on a hypothesis that anticipates what is going to happen. Carefully designed experiments should then test the implications of hypotheses in order to confirm their plausibility. Random experiments are, according to Rohault, useless because they result in a mere accumulation of facts. But for Rohault, the proper purpose of experimental procedures is to "discover the truth," which means to decide among competitive identifications of the causes. The result of repeated anticipated experience should be a coherent system of validated explanations.

This concept of experimental practice is different from the English experimental tradition embodied by the Royal Society, which aimed at col-

\footnotetext{
${ }^{37}$ Ibid.

${ }^{38}$ Cf. Dobre, "Rohault's Cartesian Physics," 210-12.

${ }^{39}$ Rohault, Traité, unpaginated "Préface"; Rohault, System, unpaginated "Preface."

${ }^{40}$ Ibid.

${ }^{41}$ Ibid.
} 
lecting and storing empirical findings - often without ambition for their causal explanation..$^{42}$ Following the Aristotelian methodological tradition, this kind of factual and descriptive knowledge providing no cognition of causes was labeled (natural) history in England. English experimentalists saw an ambition to causal knowledge (Aristotelian scientia) as a manifestation of dogmatism, authoritarianism, and an unjustified rush that wants to fix knowledge into theories and systems before having enough data. In his The History of the Royal Society (1667), Thomas Sprat writes about the intentions of Society:

The Society has reduc'd its principal Observations, into one common Stock; and laid them up in publick Registers, to be nakedly transmitted to the next Generation of Men; and so from them, to their Successors. And as their Purpose was, to heap up a mixt Mass of Experiments, without digesting them into any perfect Model; so to this End, they confin'd themselves to no order of Subjects; and whatever they have recorded they have done it, not as complete Schemes of Opinions, but as bare unfinish'd Histories. ${ }^{43}$

Another defender of the Royal Society, Joseph Glanvill writes in his Plus Ultra, or the Progress and Advancement of Knowledge (1668) about the intentions of experimental philosophers:

Their first and chief Employment is, carefully to seek and faithfully to report how things are de facto; and they continually declare against the establishment of Theories, and Speculative Doctrines which they note as one of the most miscarriages in the Philosophy of the Schools. ${ }^{44}$

And further about the Royal Society:

[...] and 'tis easie to see in the very frame of this Assembly, that they are fitted with Opportunities to amass together all the considerable Notices, Observa-

\footnotetext{
${ }^{42}$ See Peter R. Anstey and Alberto Vanzo, "Early Modern Experimental Philosophy," in Blackwell Companion to Experimental Philosophy, eds. Justin Sytsma and Wesley Buckwalter (Oxford: Wiley, 2016), 87-102; Peter R. Anstey, "Philosophy of Experiment in Early Modern England: The Case of Bacon, Boyle and Hooke," Early Science and Medicine 19, no. 2 (2014): $103-32$.

${ }^{43}$ Thomas Sprat, The History of the Royal Society (1667) (London: Knapton, 1734), 115.

${ }^{44}$ Joseph Glanvill, Plus Ultra, or the Progress and Advancement of Knowledge (London: Collins, 1668), 89.
} 
tions, and Experiments, that are scattered up and down in the wide World; and so, to make a Bank of all the useful Knowledge that is among men. ${ }^{45}$

The English experimental philosopher obviously wanted to collect data and transmit them to the next generation of scholars. Making up theories or systems, this was in their opinion a sin of arrogance and hastiness.

\section{Hypotheses}

Cartesian physics strove to interpret all natural phenomena as a result of interactions of unobservable particles or corpuscules (corpusculae) or simply - little balls (boules). These particles had only three properties: shape, size, and motion (some Cartesians included rigidity as the fourth property). Phenomena should be interpreted as caused by mechanical properties and movements of these corpuscules. ${ }^{46}$ The basis of Cartesian mechanical physics is, therefore, the creation of partial micromechanical models of particular phenomena. ${ }^{47}$ The specific configuration of invisible particles was considered a cause of an observable natural process. For example, there was a micromechanical model for celestial movements - the famous vortex theory. ${ }^{48}$ Descartes proposed further models of various natural phenomena such as light, or magnetism which Rohault and Régis later presented at public lectures.

${ }^{45}$ Ibid., 108.

${ }^{46}$ There has been a debate about the nature of early modern mechanical philosophy which I do not want to enter here. Overviews of the debate can be found in Sophie Roux, "From the Mechanical Philosophy to Early Modern Mechanisms," in The Routledge Handbook of Mechanisms and Mechanical Philosophy, eds. Stuart Glennan and Phyllis Illari (London: Routledge, 2017), 26-45; Helen Hattab, "Descartes's Mechanical but Not Mechanistic Physics," in The Oxford Handbook of Descartes and Cartesianism, eds. Steven Nadler, Tad M. Schmaltz, and Delphine Antoine-Mahut (Oxford: Oxford University Press, 2019), 124-37.

${ }^{47}$ See more in Stephen Gaukroger, The Collapse of Mechanism and the Rise of Sensibility: Science and Shaping of Modernity, 1680-1760 (Oxford: Oxford University Press, 2010), 194226; Stephen Gaukroger, The Emergence of a Scientific Culture: Science and the Shaping of Modernity, 1210-1685 (Oxford: Oxford University Press, 2006), 253-348.

${ }^{48}$ Eric J. Aiton, The Vortex Theory of Planetary Motion (New York: Macdonald, 1972), 4358; Stephen Gaukroger, Descartes's System of Natural Philosophy (Cambridge: Cambridge University Press, 2002), 135-60; John A. Schuster, "Waterworld: Descartes's Vortical Celestial Mechanics," in The Science of Nature in the Seventeenth Century: Patterns of Change in Early Modern Natural Philosophy, eds. Peter Anstey and John Schuster (Dordrecht: Springer, 2008), 35-79; John A. Schuster, "Cartesian Physics - 3. 2. 4. Vortex Mechanics," in Oxford Handbook of the History of Physics, eds. Jed Z. Buchwald and Robert Fox (Oxford: Oxford University Press, 2017), 73-82. 
Descartes and his followers intended these models as replacements of Aristotelian and scholastic explanations. Corpuscules were meant as substitutes for scholastic substantial forms and qualities. According to Cartesians, the advantage of their models consisted in the fact that specific configuration of corpuscules conceived as the cause of observable process was intelligible, or at least it was not occult. Corpuscular physics sought to transform all processes into comprehensible and imaginable particle interactions, which can be explained through mechanics and translated into mathematical rules if possible. ${ }^{49}$

How was a micromechanical model constructed? The Cartesian procedure can be very briefly summarized as follows: The starting point is a few general principles whose list was given by both, Régis and Rohault. These principles specify the behaviour of particles. Furthermore, we have experimental and observational findings. These are understood as the visible effects of the invisible corpuscular structure. Our task is to construct a model that is derived from principles or at least consistent with them. Actually, mere consistency was more common in Cartesian physics. The micromechanical model presents a specific configuration of corpuscules that causes the observable behaviour of the natural object as its effect. Or, the model outlines the characteristics of corpuscules that cause the observable characteristics of the sensible object. For example, in a vortex theory, particles are imagined as flowing in a large vortex due to the light of the Sun. In this way, the orbiting of planets around a central star is explained.

Cartesians considered the arrangement of particles with different properties (shape, size and motion) to be the cause determining the visible properties and behaviour of a physical object. However, this micromechanical structure of the object or phenomenon is invisible, and because it is not accessible to the empirical confirmation, it is a mere hypothesis. Nobody can know with certainty which corpuscular configuration is a true cause of the observed phenomenon. We can propose more micromechanical models which provide a plausible causal explanation of the same visible phenomenon. This means that the natural philosopher can imagine more corpuscular configurations causing the same visible effect.

This methodological difficulty was often presented by means of a comparison to a clock. The observed phenomenon is the clock face with moving hands. The inner invisible mechanical parts of the clock represent

${ }^{49}$ Cf. Andrew Janiak, "Isaac Newton," in The Oxford Handbook of British Philosophy in the Seventeenth Century, ed. Peter Anstey (Oxford: Oxford University Press, 2013), 106. 
the hidden corpuscular structure of physical objects. The philosopher can only guess the nature of the inner unobservable mechanism by which the clock is driven. This metaphor is already found in Descartes at the very end of his Principia Philosophiae:

Moreover, mechanics is a division or a special case of physics, and all the explanations belonging to the former also belong to the latter; so it is no less natural for a clock constructed with this or that set of wheels to tell the time than it is for a tree which grew from this or that seed to produce the appropriate fruit. Men who are experienced in dealing with machinery can take a particular machine whose function they know and, by looking at some of its parts, easily form a conjecture about the design of the other parts, which they cannot see. In the same way I have attempted to consider the observable effects and parts of natural bodies and track down the imperceptible causes and particles which produce them. ${ }^{50}$

Descartes admits here that he tried to explain the causes of observed phenomena in terms of invisible particles. There is no typical Cartesian emphasis on deduction or on the certainty of conclusions. Explaining visible phenomena in terms of imperceptible particles must always necessarily be hypothetical, even if the explanations produced are coherent with certain principles.

Other natural philosophers also used the clock comparison to express this approach. For example, the English experimental philosopher Robert Boyle (1627-1691) writes: "For as an artificer can set all the wheels of a clock a going, as well with springs as with weights [...] so the same effects may be produced by diverse causes different from one another." 51 And Roger Cotes (1682-1716) in his Introduction to the second edition of Newton's Principia (1713) writes: "For it is in accord with reason that the same effect can arise from several causes somewhat different from one another [...]. In mechanical clocks one and the same motion of the hour hand can arise from the action of a suspended weight or an internal spring." ${ }^{2}$

${ }^{50}$ René Descartes, Principes de la Philosophie in René Descartes: Oeuvres, vol. IXb, 321f.; quoted from René Descartes, The Philosophical Writings, trans. John Cottingham, Robert Stoothoff, Dugald Murdoch (Cambridge: Cambridge University Press, 1985), vol. I, $288 \mathrm{f}$.

${ }^{51}$ Robert Boyle, The Usefulness of Natural Philosophy, in Robert Boyle, The Works, ed. Thomas Birch (London: Rivington, 1775), vol. II, 45.

${ }^{52}$ Roger Cotes, "Editor's Preface to the 2 nd edition of Philosophia naturalis principia mathematica (1713)," in Isaac Newton: Philosophical Writings, ed. Andrew Janiak (Cambridge: Cambridge University Press, 2004), 71. 
Régis writes that in physical objects such as clocks, we see neither order nor arrangement of internal parts. The best we can do is guess this arrangement from the effects (tout le plus qu'on sçauroit faire, c'est de le deviner par les effets). ${ }^{53}$ As the Cartesian does not know which micromechanical model is true, Cartesian physics is explicitly hypothetical. Régis openly admits that "we will be forced to resort to hypotheses to account for the effects they produce as they are composed of invisible parts." ${ }^{\text {" }}$ Rohault summarizes this hypothetical and rather pessimistic methodology as follows:

Thus we must content for our selves for the most part, to find out how Things may be; without pretending to come to a certain Knowledge and Determination of what they really are; for there may possibly be different Causes capable of producing the same Effect, which we have no Means of explaining. ${ }^{55}$

In his famous article from 1966, Larry Laudan explained the hypothetical status of mechanistic philosophy as a consequence of corpuscular ontology. ${ }^{56}$ Later interprets have challenged this simple thesis.

Desmond Clarke explained the hypothetical status of Cartesian explanations by three reasons: The first reason is the imperceptibility of the causes of the most natural phenomena. Cartesian philosophers explain observable phenomena in terms of invisible entities. They are not able to observe properties of particles and they are not able to deduce them from general principles. Therefore they can only imagine configurations and properties of corpuscules. Secondly, the causal relationship between imagined causes and observed effects cannot be observed, but must be identified by "reasoning," i.e., philosophers do not see the causal relationship, they only assume causal efficacy. The third reason is that Cartesians had great doubts about the ability of the human mind to understand all natural phenomena. This was partly due to the epistemological reasons and partly to theological ones (the corrupted human nature after the Fall). ${ }^{57}$

Clarke thus interprets the hypothetical nature of Cartesian physics not as a consequence of a corpuscular ontology, but as a consequence of unavoidable methodological problems. Sophie Roux and Dennis Des Chene

\footnotetext{
${ }^{53}$ Régis, Système de philosophie, I, 274.

${ }^{54}$ Ibid., 275.

${ }^{55}$ Rohault, Traité, 21; Rohault, System, 14.

${ }^{56}$ Larry Laudan, "The Clock Metaphor and Probabilism: The Impact of Descartes on English Methodological Thought, 1650-1655," Annals of Science 22, no. 2 (1966): 73-104.

${ }^{57}$ Clarke, Occult Powers, 190; cf. also Clarke, French Philosophy, 101-10; Trevor McClaughlin, "Le concept de science chez Jacques Rohault," Revue d'histoire des sciences 30 (1977): 225-40.
} 
make a similar point, ultimately recommending a differentiation between corpuscular mechanicism (as an ontology or theory of matter) and epistemological or methodological mechanicism as a way of explaining natural phenomena. ${ }^{58}$

Can we characterize Cartesian hypothetical physics as mere instrumentalism? For example, since classical Antiquity, astronomers calculated the positions of celestial bodies (to save the phenomena) by means of theories they considered incorrect. This methodological position was traditionally called "to save the phenomena" (sozein ta fainomena - salvare apparentias). ${ }^{59}$ In the contemporary philosophy of science, this methodological position is mainly identified as instrumentalism. But Cartesians did not proceed in the same way as the astronomers.

Unlike astronomers, Cartesian physics has failed to provide quantitative predictions. Cartesian natural philosophers only converted and translated observable phenomena into corpuscular movements. This shift in semantics cannot be recognized as "saving the phenomena" because by "saving" usually the predictive ability was meant. Furthermore, astronomers explicitly considered some of their mathematical models to be false (e.g., the cinematic model called equant). Cartesian philosophers, in contrast, believed that they had compelling reasons for a realistic interpretation of their hypotheses. ${ }^{60}$

The first reason originated in the belief of Cartesians that their explanations did not contradict experience. According to Rohault, we must refuse hypotheses if they do not explain every property of the object, "or if it be evidently contradicted by any one Experiment." ${ }^{\prime 1}$ In other cases, the hypothesis is "well grounded" (bien establie) a "probable" (vray-semblable). ${ }^{62}$ In case of an explanation of particular phenomena, Cartesians often say

${ }^{58}$ Sophie Roux, "Le scepticisme et les hypothèses de la physique," Revue de synthèse 119 (1998): 211-55; Sophie Roux, "From the Mechanical Philosophy to Early Modern Mechanisms," in The Routledge Handbook of Mechanisms and Mechanical Philosophy, eds. Stuart Glennan and Phyllis Illari (London: Routledge, 2020), 26-42; Dennis Des Chene, "Mechanisms of Life in the Seventeenth Century: Borreli, Perrault, Régis," Studies in History and Philosophy of Biological and Biomedical Sciences 36, no. 2 (2005): 245-60.

${ }^{59}$ See, e.g., Bernard R. Goldstein, "Saving the Phenomena: The Background to Ptolemy's Planetary Theory," Journal for the History of Astronomy 28 (1997): 1-12; Peter Barker and Bernard G. Goldstein, "Realism and Instrumentalism in Sixteenth Century Astronomy: A Reappraisal," Perspectives on Science 6, no. 3 (1998): 232-58.

${ }^{60}$ In the next paragraphs I partially follow Clarke, Occult Powers, 208-21; Clarke, French Philosophy, 117-20; Dobre, "Rohault," 216f.

${ }^{61}$ Rohault, Traité, 20; Rohault, System, 13.

${ }^{62}$ Rohault, Traité, 20; Rohault, System, 14. 
that experience confirms their explanation. But this confirmation mostly suggests that the hypothesis is not inconsistent with observation. This principle of non-contradiction of experience is the only empirical reason for the plausibility of Cartesian hypotheses. Other reasons came from the inherent formal features of the theories.

The second reason was the coherence. Similarly as other Cartesians, Régis distinguishes between "true hypotheses" (vrayes hypothèses) and "arbitrary hypotheses" (hypothèses arbitraires). ${ }^{63}$ Arbitrary hypotheses are simply hypotheses saving phenomena and created ad hoc. The true hypotheses depend on each other and all together depend on the first principles. Régis says that by combining arbitrary hypotheses a monster emerges. By combining true hypotheses, a system is created. Régis then defines the system as a set of multiple hypotheses depending on each other and associated with the first principles in such a way that hypotheses are their necessary consequences and results. ${ }^{64}$ The true hypotheses agree with other hypotheses and are consistent with the underlying principles and laws. To put it simply, Cartesians believe that true hypotheses make the system, while arbitrary ones only the incoherent chaos of propositions.

The third reason for the realistic understanding of their explanations was drawn from the simplicity of hypotheses and their explanatory power. Simplicity meant generally not postulating unnecessary entities (powers, or qualities of particles). The explanatory power of hypothesis was determined according to the extent of individual phenomena which were explained by it. Rohault says that a hypothesis "is the more probable, by how much the more simple it is, by how much the fewer Properties were had in view, and by how much the more Properties, different from each other, can be explained by it." ${ }^{65}$

At the end of his overview of these reasons, Rohault added one important paragraph in which he protects hypotheses from apparently disconfirming evidence. Desmond Clarke interprets this rather confusing paragraph in such a way that once we have good reasons to endorse a theory, we should not be too hasty in rejecting it just because there are relevant phenomena which it fails to explain. ${ }^{66}$ Even if it seems that a well-grounded hypothesis does not agree with a singular empirical finding, it is not a sufficient

\footnotetext{
${ }^{63}$ Régis, Système de philosophie I, 278.

${ }^{64}$ Ibid., 276.

${ }^{65}$ Rohault, Traité, 21; Rohault, System, 14.

${ }^{66}$ Clarke, Occult Powers, 214.
} 
reason to abandon it. Rohault explicitly says that when conjecture is "well grounded," it does not lose its probability only because we cannot explain a property that was found experimentally and nobody had ever thought about it. ${ }^{67}$ Cartesians obviously believed that a systematic coherence of hypotheses is more convincing than empirical particulars contradicting the set of deduced propositions. Although Cartesian physics was not blind to the empirical findings and experiments, it always stressed the primary function of a system based on the first principles.

\section{Conclusions}

In the 17th century, there was a long and extensive tradition of empirical and experimental natural philosophy on the Continent. Cartesians took part in this movement even if only in a limited way. Although they conducted experiments, they did it as a part of public lectures whose purpose was didactic. They wanted to rather stress the explanatory power of Descartes's corpuscular philosophy than to experimentally discover something new. Cartesian natural philosophers were more concentrated on establishing and defending a system of natural philosophy that should include both the general physical principles and experimental results available in the second half of the 17th century. The primary function of this system was to replace Aristotelian scholastic natural philosophy. Thus, the reference point of Cartesian natural philosophy was the scholastic system of knowledge, not nature. Cartesians primarily did not want to explain natural phenomena. In the first place, they wanted to replace the Aristotelian system of explanations with their own. That was also one of the reasons why Cartesian natural philosophy did not become original, creative and innovative research.

Cartesian natural philosophy of the second half of the 17th century remained scientifically sterile. The Cartesians made no major discovery or significant theory. On the other hand, Cartesian natural philosophy stimulated many debates and investigations that in turn resulted in groundbreaking scientific results.

I also believe that Cartesianism has contributed to the development of modern science in another indirect sense. Cartesianism emphasized the hypothetical, probable and temporary nature of philosophical knowledge. I believe that the admission of hypotheses freed natural philosophy from traditional philosophical emphasis on certain and demonstrated knowl-

${ }^{67}$ Rohault, Traité, 21; Rohault, System, 14. 
edge. In the seventeenth century, the development of mechanistic natural philosophy and experimental practices resulted in the awareness of the provisional and incomplete character of natural knowledge. Therefore hypothetical methodology made it possible to understand natural philosophy as an open, unfinished process of exploration involving generations of collaborating scientists. This means that hypotheses helped to understand scientific knowledge as something that is subject to progressive and slow advancement. This meta-scientific idea of progress was highly important for the further development of science because it worked as a mechanism stimulating further research: progress took over the function of truth. The goal of natural philosophy is not to reach the definitive truth. The goal is the investigation itself. Christiaan Huygens, expressed this belief beautifully at the end of the century. In his Cosmotheoros (1698) he wrote: "In such noble and sublime Studies as these [i.e., natural philosophy], 'tis a Glory to arrive at Probability, and the search itself rewards the pains." ${ }^{38}$

\section{Acknowledgements:}

I thank to the anonymous reviewers for their valuable comments.

\section{Bibliography:}

Aiton, Eric J. The Vortex Theory of Planetary Motion. New York: Macdonald, 1972.

Anstey, Peter R. "Philosophy of Experiment in Early Modern England: The Case of Bacon, Boyle and Hooke." Early Science and Medicine 19, no. 2 (2014): 103-32. https://doi.org/10.1163/15733823-00192p01.

Anstey, Peter R. and Alberto Vanzo. "Early Modern Experimental Philosophy." In Blackwell Companion to Experimental Philosophy, edited by Justin Sytsma and Wesley Buckwalter, 87-102. Oxford: Wiley, 2016. https://doi.org/10.1002/9781118661666.ch6.

Barker, Peter, and Bernard R. Goldstein. "Realism and Instrumentalism in Sixteenth Century Astronomy: A Reappraisal." Perspectives on Science 6, no. 3 (1998): 232-58.

${ }^{68}$ Christiaan Huygens, Kosmotheoros in Christiaan Huygens: Cuvres complètes, vol. XXI, 689; quoted from Christiaan Huygens, The Celestial Worlds Discover'd Or, Conjectures Concerning the Inhabitants, Plants and Production, of the Worlds in the Planets (London: Childe, 1698), 10. 
Boyle, Robert. The Usefulness of Natural Philosophy. In The Works, edited by Thomas Birch, vol. II, 5-201. London: Rivington, 1772.

Clarke, Desmond. "Descartes's Philosophy of Science and the Scientific Revolution.” In The Cambridge Companion to Descartes, edited by John Cottingham, 259-85. Cambridge: Cambridge University Press, 1992. https://doi.org/10.1017/CCOL0521366232.010.

Clarke, Desmond. Descartes's Philosophy of Science. Manchester: Manchester University Press, 1982.

Clerselier, Claude. "Preface.” In Jacques Rohault, Oeuvres posthumes, unpaginated. Paris: Desprez, 1687.

Cotes, Roger. "Editor's Preface to the 2nd edition of Philosophia naturalis principia mathematica (1713)." In Isaac Newton: Philosophical Writings, edited by Andrew Janiak, 42-59. Cambridge: Cambridge University Press, 2004.

Dear, Peter. Discipline and Experience: The Mathematical Way in the Scientific Revolution. Chicago: University of Chicago Press, 1995. https://doi.org/10.7208/chicago/9780226139524.001.0001.

Des Chene, Dennis. “Cartesian Science: Régis and Rohault.” In Blackwell Companion to Early Modern Philosophy, edited by Steven Nadler, 183-196. Oxford: Blackwell, 2002. https://doi.org/10.1002/9780470998847.ch13.

Des Chene, Dennis. "Mechanisms of Life in the seventeenth century: Borreli, Perrault, Régis." Studies in History and Philosophy of Biological and Biomedical Sciences 36, no. 2 (2005): 245-60. https://doi.org/10.1016/j.shpsc.2005.03.002.

Descartes, René. CEuvres. Edited by Charles Adam and Paul Tannery. Paris: Vrin, 1897-1913.

Descartes, René. The Philosophical Writings of Descartes. Translated by John Cottingham, Robert Stoothoff, Dugald Murdoch. Cambridge: Cambridge University Press, 1985. https://doi.org/10.1017/CBO9780511818998.

Dobre, Mihnea. "Jacques Rohault and Cartesian Experimentalism." In The Oxford Handbook of Descartes and Cartesianism, edited by Steven Nadler, Tad M. Schmaltz, and Delphine Antoine-Mahut, 47-88. Oxford: Oxford University Press, 2019. https://doi.org/10.1093/oxfordhb/9780198796909.013.24.

Dobre, Mihnea. “Jacques Rohault's Mathematical Physics.” HOPOS: The Journal of the International Society for the History of Philosophy of Science 10, no. 2 (2020): 414-39. https://doi.org/10.1086/710179. 
Dobre, Mihnea. “Rohault's Cartesian Physics.” In Cartesian Empiricisms, edited by Mihnea Dobre and Tammy Nyden, 203-26. Dordrecht: Springer, 2013.

https://doi.org/10.1007/978-94-007-7690-6_9.

Fontenelle, Bernard, de. Histoire de l'Académie Royale des sciences. Paris: Martin Coignard, 1733.

Garber, Daniel. "Philosophia, Historia, Mathematica: Shifting Sands in the Disciplinary Geography of the Seventeenth Century.” In Scientia in Early Modern Philosophy, edited by Tom Sorell, G. A. J. Rogers, and Jill Kraye, 1-19. Dordrecht: Springer, 2010. https://doi.org/10.1007/978-90-481-3077-1_1.

Gaukroger, Stephen. Descartes's System of Natural Philosophy. Cambridge: Cambridge University Press, 2002. https://doi.org/10.1017/CBO9780511606229.

Gaukroger, Stephen. The Collapse of Mechanism and the Rise of Sensibility: Science and Shaping of Modernity, 1680-1760. Oxford: Oxford University Press, 2010. https://doi.org/10.1093/acprof:oso/9780199594931.001.0001.

Gaukroger, Stephen. The Emergence of a Scientific Culture: Science and the Shaping of Modernity, 1210-1685. Oxford: Oxford University Press, 2006.

https://doi.org/10.1093/acprof:oso/9780199296446.001.0001.

Goldstein, Bernard R. “Saving the Phenomena: The Background to Ptolemy's Planetary Theory.” Journal for the History of Astronomy 28 (1997): 1-12. https://doi.org/10.1177/002182869702800101.

Hamou, Philippe. "Sur les origines du concept de méthode à l'âge classique: La Ramée, Bacon et Descartes." Revue LISA 12, no. 5 (2014). https://doi.org/10.4000/lisa.6249.

Harrison, Peter. "Physicotheology and the Mixed Sciences." In The Science of Nature in the Seventeenth Century. Patterns of Change in Early Modern Natural Philosophy, edited by Peter Anstey and John Schuster, 165-83. Dordrecht: Springer, 2008. https://doi.org/10.1007/1-4020-3703-1_7.

Hattab, Helen. "Descartes's Mechanical but Not Mechanistic Physics." In The Oxford Handbook of Descartes and Cartesianism, edited by Steven Nadler, Tad M. Schmaltz, and Delphine Antoine-Mahut, 124-37. Oxford: Oxford University Press, 2019. https://doi.org/10.1093/oxfordhb/9780198796909.013.7.

Huygens, Christiaan. "De la vie de M. des Cartes par Baillet.” In Christiaan Huygens: Cuvres complètes, vol. X, 402-6. La Haye: Nijhoff, 1905. 
Huygens, Christiaan. The Celestial Worlds Discover'd Or, Conjectures Concerning the Inhabitants, Plants and Production, of the Worlds in the Planets. London: Childe, 1698.

Huygens, Christiaan. Kosmotheoros. In Christiaan Huygens: Cuvres complètes, edited by J. A. Vollgraff, vol. XXI, 655-841. La Haye: Nijhoff, 1944.

Janiak, Andrew. "Isaac Newton." In The Oxford Handbook of British Philosophy in the Seventeenth Century, edited by Peter Anstey, 98-123. Oxford: Oxford University Press, 2013.

Laudan, Larry. "The Clock Metaphor and Probabilism: The Impact of Descartes on English Methodological Thought, 1650-1655.” Annals of Science 22, no. 2 (1966): 73-104. https://doi.org/10.1080/00033796600203065.

Le Rond D’Alembert, Jean. "Discours préliminaire des editeurs." In Encyclopédie our Dictionnaire raisonné des sciences, des arts et des métiers, edited by Denis Diderot and Jean Le Rond D’Alembert, i-xliv. Paris: Briasson, 1751. https://doi.org/10.5962/bhl.title.82225.

Malebranche, Nicolas. De la recherche de la verité. In Nicolas Malebranche: Oeuvres, edited by Geneviève Rodis-Lewis, vol. I. Paris: Gallimard, 1979.

McClaughlin, Trevor. "Descartes, Experiments, and a First Generation Cartesian, Jacques Rohault." In Descartes's Natural Philosophy, edited by Stephen Gaukroger, John Schuster, and John Sutton, 330-42. London: Routledge, 2000.

McClaughlin, Trevor. "Le concept de science chez Jacques Rohault." Revue d'histoire des sciences 30 (1977): 225-40. https://doi.org/10.3406/rhs.1977.1502.

McClaughlin, Trevor. "Was There an Empirical Movement in Mid-seventeenth Century France? Experiments in Jacques Rohault's Traité de physique." Revue d'histoire des sciences 49 (1996): 459-80. https://doi.org/10.3406/rhs.1996.1266.

McMullin, Ernan. "Explanation as Confirmation in Descartes's Natural Philosophy." In A Blackwell Companion to Descartes, edited by Janett Broughton and John Carriero, 84-102. Oxford: Blackwell, 2008.

https://doi.org/10.1002/9780470696439.ch6.

Nadler, Steven, Tad M. Schmaltz, and Delphine Antoine-Mahut, eds. The Oxford Handbook of Descartes and Cartesianism. Oxford: Oxford University Press, 2019.

Régis, Pierre-Sylvain. Système de philosophie, contenant la logique, la métaphysique, la physique et la morale. Paris: Thierry, 1690. 
Rohault, Jacques. System of Natural Philosophy Illustrated with Dr. Samuel Clarke's Notes Taken Mostly Out of Sir Isaac Newton's Philosophy. 2 vols. London: John Knapton, 1735.

Roux, Sophie. "An Empire Divided: French Natural Philosophy (1670-1690).” In The Mechanization of Natural Philosophy, edited by Daniel Garber and Sophie Roux, 55-96 Dordrecht: Springer, 2013. https://doi.org/10.1007/978-94-007-4345-8_3.

Roux, Sophie. "From the Mechanical Philosophy to Early Modern Mechanisms." In The Routledge Handbook of Mechanisms and Mechanical Philosophy, edited by Stuart Glennan and Phyllis Illari, 26-45. London: Routledge, 2017. https://doi.org/10.4324/9781315731544-3.

Roux, Sophie. "From the Mechanical Philosophy to Early Modern Mechanisms." In The Routledge Handbook of Mechanisms and Mechanical Philosophy, edited by Stuart Glennan and Phyllis Illari, 26-42; London: Routledge, 2020. https://doi.org/10.4324/9781315731544-3.

Roux, Sophie. "Le scepticisme et les hypothèses de la physique." Revue de synthèse 119 (1998): 211-55. https://doi.org/10.1007/BF03181379.

Roux, Sophie. "The Two Comets of 1664-1665: A Dispersive Prism for French Natural Philosophical Principles." In The Idea of Principles in Early Modern Thought, edited by Peter R. Anstey, 98-147. London: Routledge, 2017. https://doi.org/10.4324/9781315452692-5.

Roux, Sophie. “Was There a Cartesian Experimentalism in 1660s France?” In Cartesian Empiricisms, edited by Mihnea Dobre and Tammy Nyden, 47-88. Dordrecht: Springer, 2013. https://doi.org/10.1007/978-94-007-7690-6_3.

Schüller, Volkmar. "Samuel Clarke's Annotations in Jacques Rohault's Traité de Physique, and How They Contributed to Popularising Newton's Physics." In Between Leibniz, Newton, and Kant, edited by Wolfgang Lefèvre, 95-110. Dordrecht: Springer, 2001. https://doi.org/10.1007/978-94-015-9729-6_5.

Schuster, John A. "Cartesian Physics - 3. 2. 4. Vortex Mechanics." In The Oxford Handbook of the History of Physics, edited by Jed Z. Buchwald and Robert Fox, 73-82. Oxford: Oxford University Press, 2017. https://doi.org/10.1093/oxfordhb/9780199696253.013.4.

Schuster, John A. "Waterworld: Descartes's Vortical Celestial Mechanics." In The Science of Nature in the Seventeenth Century. Patterns of Change in Early Modern Natural Philosophy, edited by Peter Anstey and John Schuster, 35-79. Dordrecht: Springer, 2008. https://doi.org/10.1007/1-4020-3703-1_3. 
Daniel Špelda

Spink, Aaron. “The Experimental Physics of Jacques Rohault.” British Journal for the History of Philosophy 26, no. 5 (2018): 850-70.

https://doi.org/10.1080/09608788.2017.1379004. 